\title{
A PAPER CALIPHATE: UNDERSTANDING THE ISLAMIC STATE THROUGH ITS DOCUMENTS
}

\section{UM CALIFADO DE PAPEL: ENTENDENDO O ESTADO ISLÂMICO POR MEIO DE SEUS DOCUMENTOS}

\author{
Diogo Bercito ${ }^{1}$
}

\begin{abstract}
The Islamic State is a terror organization that distinguishes itself from other similar groups by the establishment of a bureaucratic structure that projects the image of a state. This essay investigates documents produced in Iraq under the banner of the caliphate. These documents reveal an administration that enforces itself over a large territory. Their analysis points to a particular view of government presented as Islamic, which this investigation compares with precedents set throughout Islamic history, while traces of the modern conception of a state are found to be salient.
\end{abstract}

Key-words: Islamic State, Shari`a, Caliphate, Iraq, Syria

\begin{abstract}
Resumo
0 Estado Islâmico é uma organização terrorista que se distingue de outros grupos similares pelo estabelecimento de uma estrutura burocrática que projeta a imagem de um Estado. Este ensaio investiga documentos produzidos no Iraque sob o estandarte do califado. Esses documentos revelam uma administração que se impõe em um extenso território. Sua análise aponta para uma visão particular de governo apresentada como islâmica, que essa pesquisa compara com precedentes estabelecidos durante a história islâmica, enquanto traços de uma concepção moderna de Estado são evidentes.
\end{abstract}

Palavras-chave: Estado Islâmico, Shari`a, califado, Iraque, Síria

\section{INTRODUCTION: THE DEBATE ABOUT THE ISLAMIC STATE²}

\subsection{Terror and governance}

Since its conception the Islamic State has been imposing its reign of terror over a stretch of land the size of Belgium. The caliphate, self-proclaimed in the Iraqi city of Mosul mid-2014, was built with the bricks of former administrations of Syria and Iraq, taking advantage of both its structures and personnel. From outside its borders, this endeavour

\footnotetext{
${ }^{1}$ Diogo Bercito is a reporter with Brazilian newspaper Folha de São Paulo. He has been based in Jerusalem, Beirut and Cairo. This paper was written in 2015 during his master's degree in Contemporary Arabic and Islamic Studies at Universidad Autónoma de Madrid, tutored by Maribel Fierro. Lattes: http://lattes.cnpq. br/6247071137720148. Contact: diogo.bercito@gmail.com

${ }^{2} \mathrm{~A}$ number of people contributed to this paper in countless ways. I would like to thank four of them here: Ana Belén Soage, for very kindly reading my draft and suggesting helpful edits; Wael Hallaq, whose work was a milestone piece for this study and who also had the kindness of reading my draft; Meredith Mayer, who reviewed my writing. And finally, I must thank my tutor, Maribel Fierro - it is impossible to express how fundamental a role she played.
} 
has the face of a nightmare made of victims spread on the sand and heads cut off in front of cameras. But, as this paper will argue, the study of the Islamic State should not be focused only on corpses and swords - instead, its rule could also be seen as the result of a caliphate built over paper, more than over blood.

The amount of success achieved by this organization does not come solely from the random exercis e of violence and terror over a large population. The fact that the Islamic State has been resisting international efforts to extinguish its self-proclaimed caliphate is an indication that the structure supporting it in its territory is sound. It is built as a state, and works as such by providing basic services to citizens (Weiss \& Hassan, 2015). In fact, this state-like structure constitutes the base of the project carefully planned by the Islamic State leadership.

It is in its nation-building efforts that this organization distinguishes itself from its predecessors, since the once predominant thinking led by Al-Qaeda in the field of radical Islam considered the establishment of a state as a distant goal ${ }^{3}$. Understanding the Islamic State by focusing on its commitment to act like a government will therefore advance the current debate, which seems to be stuck on a negative definition of this organization, perceived by foreign experts as neither Islamic nor as a state. Firstly, however, how to define what is Islamic and what it is not is hampered by the existence of diversity of interpretations and the lack of a centralized and hierarchical structure of religious authority as central features of Sunni Islam, thus allowing for a highly pluralistic understanding of "orthodoxy". An article recently published by the Atlantic magazine (Wood, 2015) led to a broad discussion on this issue among academics that reflected - once again - the contentious character of attempts at labeling actors and actions as Islamic or at withdrawing such labels. Secondly, it could indeed be argued that the Islamic State does not function as a modern state in some of its prerogatives, even though it appears to fulfill a raw definition of state as an entity with a monopoly on violence (Weber, 1946).

Besides conceptual reservations over international efforts to portray the Islamic State as a non-state actor, the analysis of its structure would benefit by taking it at face value. That is to say, when dealing with an organization that understands and promotes itself as a state, there are advantages on accepting it as such, at least in the sense that this approach would make it possible to understand it in its own terms instead of relying on external definitions. This can be proven wrong by time - but so far former and current strategies could hardly be described as successful, if judging by the continuous challenge posed by the Islamic State both to the Middle East and to foreign governments under its threat.

From this perspective, the attempt will be made here to read a set of documents

\footnotetext{
${ }^{3}$ In a lecture presented at the Belfer Center for Science and International Affairs at Harvard University, Yezid Sayigh argued, in this sense, that while Al-Qaeda considers "jihad" as a priority, the Islamic State sees violence as a way of achieving its goal of establishing a state, and not as the goal itself (2015).

${ }^{4}$ See on this issue "The limits of Islamic orthodoxy" (Calder, 2000).
} 
produced by the Islamic State and thusly understand its administrative structure and its particular view on Islamic governance. The documents selected are those issued by offices in the Iraqi governorate of Nineveh from mid-2014 until mid-2015, and they include rulings on education, health and public services.

\subsection{The Islamic state}

In its name, the terror organization Islamic State refers to a concept of governance based on Islamic law. It understands that the caliphate, or imamate, is the adequate path for ruling a Muslim community in its territory - in fact, in the first issue of its own magazine, Dabiq, the Islamic State argued for this political arrangement, tracing it back to the leadership of the prophet Abraham ("The Return of Khilafah", 2014) ${ }^{5}$. The first decades of Islam are set as the standard of an ideal rule, by establishing that the best governance of a Muslim society was seen during the reign of caliphs Abu Bakr, Omar, Uthman, and Ali, known collectively as the four "rightly-guided caliphs" (632-661). That has indeed been a common reference through the centuries in the Muslim world, though the conceptualization of what an Islamic state is as a political entity carries traces of a more recent articulation (Afsaruddin, 2006: 154).

The caliphate was officially abolished as an institution in 1924 by the secular reforms of Turkish leader Mustafa Kamal, known as Atatürk. Since then, authors have described efforts by some sectors of Muslim societies towards the redevelopment of an Islamic state, sometimes by the reinforcement of Islamic law as the basis for legislation, or by the reinstalment of the caliphate itself as a political structure. This question was dealt with by Egyptian Al-Azhar-trained Ali Abdel Razek, who in the beginning of the 20th century stated that there is nothing in the Quran or in other accepted Islamic traditions that points to the caliphate as a religious obligation. He saw Islam as a message from God rather than a system of government, and a religion rather than a state. Razek went further, considering that very structure as the source of grievances in the Muslim world.

The caliphate has always been, and still remains, a disaster for Islam and for Muslims. It has been a constant source of evil and corruption. [...] Our religion is not dependent, any more than our temporal affairs, on the "caliphate" (Razek, 2012: chapter 3).

The debate around the caliphate took different paths since its extinction, and Razek's "refutation of the caliphate stands at the beginning of alternative ways of Islamic political thinking, both secular and Islamist" (Kersten, 2015). The possibility of shaping a government based on the rule of Islamic law is studied by scholars with diverse

${ }^{5}$ During a lecture at the British Association for Islamic Studies Annual Conference, 2015, Carool Kersten suggested the particular influence of the Salafi scholar Abu Muhammad al-Maqdisi and his book Millat Ibrahim on this idea. 
conclusions. Noah Feldman argued, for instance, when specifically discussing the views of Islamist groups, that the Islamic state as a concept has a "reasonable chance of establishing political justice and, through it, popular legitimacy" if it includes an institutional authority with the capacity to "check executive power in the name of the law", a role traditionally played by scholars during history (Feldman, 2008: introduction). Although

The Islamic state envisioned by the Islamists could not be more different from the Islamic state of the classical constitutional order. The old Islamic state was rendered Islamic by the scholars and on their account. The new Islamic state is Islamic despite the scholar's absence from its institutions (Feldman, 2008: part 3).

Also responding to Islamist organizations, Wael Hallaq supported that an Islamic state is an impossibility and a contradiction regardless of the definition of a modern state. He saw, for instance, the modern state as necessarily sovereign, whereas by Islamic law "the sovereign is God and God alone" (Hallaq, 2013: 49).

Both Feldman and Hallaq focused on Islamist movements such as the Muslim Brotherhood when writing their views on the Islamic state. According to these views, such groups are willing to adjust their demands to the existing framework of a modern state, and shape their "Islamicity" thusly. We would more specifically place the Islamic State in the field of Salafism, where the conditions for the establishment of an Islamic governance are much more restricted. That seems to be this organization's own definition, since a former leader of the Islamic State, Abu Omar al-Baghdadi, appealed in a 2007 audio address to "all Sunnis, and to the young men of Jihadi-Salafism in particular, across the entire world" (Bunzel, 2015) .

The terror organization Islamic State is a recent entity in face of this centuryold debate, if one sees it as the result of its caliphate proclamation. But this enterprise has roots deeper than that, reaching Jordan and Afghanistan and being shaped by the American invasion of Iraq in 2003. This investigation has no ambition to trace the detailed trajectory of its former structures, which were part of a complex dynamic between the political context and its leadership, but a short summary of its history can confirm the statement - central to this work - that the Islamic State has set its ability to rule a territory as its determinant of success (Lister, 2014).

A Brookings Doha Center study points to 1999 as a key-date for the development of what we know today as the Islamic State, when Jordan released Abu Musab al-Zarqawi from prison. Zarqawi, whose terror organization Tawhid wa al-Jihad was later progressively

\footnotetext{
${ }^{6}$ We adhere here to the definitions given by Luz Gómez García (2009). She defined "Salafism" as "ideología internacionalista que propugna la instauración de un orden islámico universal que recupere las esencias del Islam, hoy en día corrompidas" (294). "Islamism" was described by this same author as "conjunto de proyectos ideológicos de carácter político cuyo paradigma de legitimación es islámico” (165).
} 
transformed into the current Islamic State, showed an understanding that a caliphate could be established and thrive as a result of regional disorder ${ }^{7}$. Zarqawi's political views seem to be so central to the Islamic State doctrine that he is quoted in the first page of every issue of Dabiq: "The spark has been lit here in Iraq and its heat will continue to intensify by Allah's permission until it burns the Crusader army in Dabiq" "The Return of Khilafah", 2014).

In terms of seeing the Zarqawi-led terror structure as a state vision, it is of special interest to point to one specific transformation among the many changes that this organization had in its name over the years. In 2006, what was then known as the Majlis Shura al-Mujahedin (MSM) was disbanded and shaped again as the Islamic State in Iraq (ISI). Lister notes:

The decision to rebrand the MSM as the ISI in 2006, and specifically as a dawla (state), is symbolically crucial. By perceiving and presenting itself as a state, IS has sought to control and govern territory and maintain a cabinet of ministers responsible for a broad range of "ministries," incorporating military, civil, political and financial duties (Lister, 2014: 21).

With the death of Zarqawi in 2006, this structure came into the hands of Abu Ayyub al-Masri and Abu Omar al-Baghdadi's dual leadership. It was then inherited by the self-proclaimed caliph Abu Bakr al-Baghdadi, with the key-role of his right-hand Haji Bakr when building its military capability (Reuter, 2015). It was Haji Bakr, for instance, that "purged the organization of most of its non-Iraqi senior leadership, replacing it with experienced former Baathist security officers" (Lister, 2014: 19). And, if it was chaos that it needed to make a move and establish its role over a stretch of land, it was chaos that the Islamic State found with the uprising in Syria, early 2011, and the following civil conflict that rose in the country, spilling over into its neighbor Iraq. By mid-2014, the Islamic State declared its caliphate headed by al-Baghdadi. As of that year, it commanded as many as 31,000 fighters in a "highly bureaucratic organization focused on earning a sufficient income to finance widespread governance initiatives" (Lister, 2014: 2).

In this same line, in a book published on the Islamic State, Spanish journalist Javier Martín pointed to the ability of this organization to finance itself and considered it as a "proto-state" that manages a wide social fabric (Martín, 2015: 15). Italian reporter Loretta Napoleoni, also when writing about this subject, recognized on it a far-reaching state appearance, since

No other armed organization has shown such insight into, and political intuition regarding, the domestic politics of the Middle East and Muslim immigrant's frustration all over the world. No other armed organization has so successfully adapted to contingent factors, such as the provision of basic socioeconomic

\footnotetext{
${ }^{7}$ This specific plan to create a state out of chaos is present in the text of The Management of Savagery (Naji, 2006), a work widely read among the ranks of the Islamic State (Weiss and Hassan, 2015).
} 
infrastructure and business partnership with local authorities in the territory it controls, in its efforts at nation-building (Napoleoni, 2014: introduction).

And

The Caliphate considers the maintenance of law and order to be its responsibility, and implements them, if in a rough and rudimentary manner. The Caliphate is also responsible for the protection of the areas under its command from enemy attack. Hence, the Islamic State also takes up the task of national security. Law and order and national security are the two key indications that distinguish a modern state from a pre-modern enclave run by war lords and barons (Napoleoni, 2014: chapter 8).

\section{DOCUMENTS AND THE HISTORY OF ISLAMIC SOCIETIES}

The type of analysis chosen here - the study of a state-like organization through its written documents - has much to do with the traditional approach taken by history. Historiography has indeed questioned itself over and again about what could be its sources of information when building a present image of the past. What Fustel de Coulanges understood of this question later became an axiom which prescribed that history is done by texts (Le Goff, 1990). Le Goff saw the work of a historiographer as being that of analyzing a "document" as a "monument", that is to say, as a sign from the past. The transformation of a document into a monument, according to him, is related to its use by power (Le Goff, 1990: 545).

But, for reasons that will be exposed below, the writing of the history of Islamic societies before the Ottomans if compared to that of Latin Christendom has to be carried out - with some exceptions - without recourse to documents preserved in archives. This gap contributes to the tension between an idealized past and its historical reality, which modulates the field in which Islamist and Salafist groups work. In this sense, the very definition of what is the historical model of a caliphate is subject to discussion between different political actors, with no consensus on what is Islam, who is a Muslim and what are their references.

Historiography in this field has on several occasions gone back to this question, either by asking itself how to deal with the small amount of documents that have been preserved, or by raising the question of why Muslim literate societies did not hoard documents (with the exception of the Ottoman Empire) as it was done at the same time in Europe ${ }^{8}$. Although this discussion relates to the field of history, and its methods could not be identical to those applied to the study of a contemporary phenomenon such as the Islamic State, it does provide useful considerations and tools for dealing with written

\footnotetext{
${ }^{8}$ By reading How Islamic law held back the Middle East (Kuran, 2011), one could relate the absence of archives with a general lack of modern institutions, in which the author identifies a key for the divergence of development between Islamic societies and Europe.
} 
documentation in this field. It could be argued, for instance, that it points to the importance of collecting and organizing these documents on an archive while they are available. This problem was discussed by Manzano Moreno when introducing the publication of a large array of documents from the Medieval Muslim world, which by themselves were seen as a proof that "from a very early date Arab society relied heavily on documents not only as means to present and represent itself, but also as instruments of social control" (Manzano Moreno, 2007: xx). That statement led to a further question: if these written documents did exist, "how do we explain the disappearance of the thousands of records which were necessary to regulate the complex administration of such huge territories?" (Manzano Moreno, 2007: xxiii). But the answer could be that the relevant phenomenon is not the disappearance of documents in the pre-modern Muslim world, but its keeping in Medieval Europe, where they were "accumulated, filed and looked after throughout the centuries because their contents were considered useful by certain institutions which claimed to have deep historical roots and were ready to use such roots as proof of their legitimacy" (Manzano Moreno, 2007: xxiv).

This difference also marked distinctive perceptions of history. Western European institutions generated documents because they were essential parts of their raison d'etre. As fundamental pieces for the creation of an historical memory of the institution, these documents proclaimed that the preservation of the past could provide useful arguments for the articulation of the present. This does not seem to have been the case in Islamic societies, where history never played such an important role as other arguments of legitimacy, like divine sanction or moral standing did. [...] Written records disappeared en masse because they could not find their way to the appropriate repositories (Manzano Moreno, 2007: xxvi).

There is no evidence so far that the Islamic State is archiving its documents in any fashion. Repositories, such as the one that provided the corpus for this study, are therefore the work of external actors. But by reading the written decisions issued by this terror organization we are convinced of the importance of these papers on articulating the legitimacy of a political project. This conclusion has a parallel on a study conducted by Sijpesteijn on papyri found in the Fayyum, in Egypt ${ }^{9}$. In her work on those administrative documents she noted, for example, that written documents issued by governments establish and communicate an image of the state, since recording and disseminating practical information is not the only function of a text (Sijpesteijn, 2013: 218). Therefore

\footnotetext{
${ }^{9}$ Sijpesteijn was able to infer detailed information from administrative documents, describing the crop of wheat, barley and beans as they were mentioned in the letters of her corpus, the same as grapes, wine, fruit and sycamore trees (Sijpesteijn, 2013: 30). But she had to ask herself to which extent the documents preserved in that region of Egypt could be indicative of a wider post-conquest situation. She had to decide, for instance, if it would be possible to extrapolate from the Fayyum to the rest of Egypt, or if the set of papyri studied should be treated as a special case (Sijpesteijn, 2013: 32). As it was established that those documents are only "an infinitesimal fraction of the total number of written texts produced" in the region (Sijpesteijn, 2013: 218), any information extracted from them had to be treated as such - that is to say that they could not safely be seen as a representation of a whole, without a careful analysis of the context in which they were produced and circulated.
} 
"texts function in ways that extend beyond their ostensible semantic content, conveying symbolic meanings and fulfilling rhetorical goals" and

Letters issued by government offices, for example, functioned as symbols of sovereignty, transmitting important messages about authority and statehood and projecting images of the state's self-representation. [...] On a smaller scale, official letters delegated the sender's authority to the letter-bearer, emphasizing the latter's ties to the ruling power and offering him a tool with which to establish and assert his authority over the addressee. Supported by seals, and other external characteristics, these letters were also pictures, signs that would have had immediate associations of power, public or private sphere, and social context, for their senders, deliverers, users, and viewers (Sijpesteijn, 2013: 219).

When dealing with a self-declared caliphate, the Islamic State, we are specially interested on the self-representation of a state as described above by Sijpesteijn. We therefore studied a set of papers issued by this organization looking for insights on its administrative structure and its view on Islamic governance. During the whole process, the relation between power and documentation was ever present, reminding us of the idea expressed by Le Goff that the transformation of a document into a monument depends on its use. Furthermore, we noticed the difference between modes of discourse, such as audio announcements by caliph Abu Bakr al-Baghdadi and papers issued by offices of the Islamic State, and between enunciation and action — though those questions could not be further analyzed in this paper since they escaped its frame of study.

The corpus of our analysis is based on a set of written decisions issued by the Islamic State on the governorate of Nineveh ${ }^{10}$. Facing the sheer amount of available material, which would impose a wider focus and require a longer period of analysis, we decided to go for a section limited by geography. Nineveh was the obvious choice not only because of the variety of papers that have reached us from there, but also because it is the province of the city of Mosul, the Iraqi capital of the Islamic State. It could be argued that since Raqqa, in Syria, is the capital of the whole self-declared caliphate, this investigation should have been conducted with written evidence from there. But while Raqqa has a population of around 200,000 people, Mosul gathers almost 2 million inhabitants, therefore Islamic State decisions in that governorate cause a considerably wider impact.

It is possible that some of these documents are forgeries, and that was a constant

\footnotetext{
${ }^{10}$ The written documents here analyzed were all archived by Aymenn Jawad al-Tamimi, a graduate from Brasenose College, Oxford University, and a Shillman-Ginsburg Fellow at the Middle East Forum (an American conservative think-tank criticized for what are pointed as islamophobic stances). He collected these papers from Islamic State-related accounts in social media, corroborating with news reports and local testimonies. Some of the documents came from anti-Islamic State actors, also corroborated by Tamimi. He kindly authorized the use of the information by this investigation. Tamimi gathered a large number of papers in his online archive, but has not proceeded to a deeper analysis of their structure and content, as it was not the goal of his project. Some of his remarks are quoted in these pages, as well as his translation of the documents.
} 
preoccupation during this study. There are several reasons for this concern. For example, creating fake papers would present an extreme image of the Islamic State, therefore serving the interest of a wide range of groups such as the Syrian and Iraqi regimes or Western intelligence services. But our analysis of the papers lead us to treat them as authentic documents. For instance, a number of signs reassured us of that, such as the recurrence of specific signatures on the bottom of documents or the communication between different bureaus as seen in their decisions.

We therefore reached the corpus of 13 documents issued by 8 different bureaus ${ }^{11}$, selected from a wider range of papers. From now on they will be quoted here by the initial letter of its bureau and a number, such as T1 for the first document issued by the Bureau of Education (in Arabic, Ta lim). The process of determining the documents to be studied provided us with an encompassing idea of what is the general situation regarding this corpus, and that was another important part of assuring us that these were authentic written evidences and that they form part of a project, thus not being exceptional when dealing with the Islamic State and its view on governance.

The first step of our analysis was the study of how this written evidence is materially presented, since its appearance also communicates a message to its readers. The second step was gathering from them information about the structure of the Islamic State in terms of how its offices are seen and organized. Since they were issued by specific bureaus, and in a specific fashion, we could reach conclusions about the project of a government related to a past period of history and ideally distant from the Western modern state. The third and last step concerned the content of this corpus, in what it informed us about the Islamic State view of Islamic governance. After these three steps we were able to draw our final considerations.

\section{DOCUMENTS AND THEIR USE BY THE ISLAMIC STATE}

\subsection{Material appearance}

In terms of its material appearance, the evidence analyzed here shares a number of common features, pointing both to coincident values and recurrent structures. The whole corpus is, for instance, introduced by the Islamic formula of "basmallah" ("in the name of God, the most gracious, the most merciful"). It is also recurrent that these papers bear in their headers the flag of the Islamic State - a black banner with the "shahada" ("there is no god other than God") and the seal of the prophet ("Muhammad is the messenger of

${ }^{11}$ These documents couldn't be included here in a legible way, thus they are available online at this link: http://bit.ly/IslamicStateDocuments. 
artigo

God" $^{12}$. The documents also show clearly the name of the Islamic State and that of the bureau that issued them, besides a recurrent use of the Islamic calendar, in several cases to the detriment of the Gregorian calendar. Still concerning the religious element, Quranic quotation is present in papers such as $\mathrm{H} 1$.

It is in the decisions published by the Bureau of Education, though, that we see more clearly a coherent design, with an almost identical structure on T1, T2, T4 and T5, which could point to the use of a common template. That they are issued showing recurrent traces of design leads us to two non-excluding hypothesis: they were written by the same person and they were produced by the same office. In case some of them are later to be proved forgeries, it would then be an indication that the fake papers were fashioned in a way to resemble what is seen as the authentic version. Regardless of what we determine by these similarities, they assure us of the fact that there is something we can perceive as a common project.

Another telling indication of a shared structure, which can also further assure us of the legitimacy of our corpus, is the presence of handwritten signatures on the bottom of some of these documents, for instance KH2 and T1. We can safely assume that T1, T3 and $\mathrm{T} 5$ were signed by the same person, or by a falsifier with intent to appear as such, and we can also infer that he is a different official than the one who signed KH2.

\subsection{Bureaucratic structure}

Most of the documents that are part of this investigation were issued by institutions that identify themselves by the name of "diwan", which in this context could be translated as a bureau. From the written evidence here studied, it appears that these departments rule over their respective fields as ministries would do in a Western modern conception of the state. This hypothesis is backed by two documents issued by the Bureau of Education, explicitly ordering to change the denomination of this office from "ministry" to "bureau" when dealing with official registries (T1, T5). The same two papers tell public employees to replace references of the Government of Iraq by those of the Islamic State, in a way which reinforces the relationship established at the one hand between the "ministry" and the former administration and, on the other, between the "bureau" and the Islamic State.

Even though the contemporary use of the word "diwan" by a government is not exclusive to the Islamic State, terminology here is a key-aspect. The establishment of a structure based

\footnotetext{
${ }^{12}$ Concerning the flag of the Islamic State, this symbol itself holds several cultural references of interest. The black color could, for example, recall a black banner traditionally associated with Muhammad. Additionally, the phrase "Muhammad is the Messenger of God" is inverted in its writing, so that the word "Muhammad" appears below the word "God", in a strong statement.
} 
on a bureau, instead of a ministry, is telling of a diverse view of governance that relates to a pre-modern period and, therefore, distances itself from the administration it replaced.

The "diwan" is commonly translated as a "collection of poetry or prose, a register or an office", according to the Encyclopaedia of Islam. Its etymology is debated, with views including a Persian origin ("dev", meaning "mad", to describe secretaries) or an Arabic one ("dawwa", "to collect"). In an administrative context it was first meant as a register for troops and, then, as any register, being later used for describing an office (Duri et al., 2015).

Historically the first "diwan" was instituted by caliph Omar (d. 644) with the intent of organizing, paying and registering the fighting forces and setting the treasury in order. That was to be known as the "diwan al-jund". A "diwan al-rasa'il" was created under caliph Mu`awiya (d. 680) for dealing with the letters he produced, as well as the "diwan alkhatam" for keeping copies of these documents, thus preventing forgery. It was also under Mu`awiya that the "diwan al-barid" was shaped with the role of a post office.

It was under caliph Abd al-Malik (d. 705) that the "diwan" was Arabized, adjusting calendars to the Muslim lunar year and removing "dhimmi" secretaries from its ranks. Later on, during Abbasid rule these bureaus were provided centralization under the office of a wazir (minister). That period saw the appearance of different sorts of offices, including the "diwan al-mazalim" (redressing of wrongs). This system was fully developed by the 9-10th centuries (Duri et al., 2015), but on the 11th century, when al-Mawardi wrote his Ordinances of Government, he mentioned the "diwan" as a "chancery", "a place for the safe-keeping of records of government functions and property, and the armies and other personnel in charge of them" (Mawardi, 2010: 217).

The history of the "diwan" goes further into the centuries and territories, developing for instance in Egypt after the Muslim conquest and taking different shapes as happened during Mamluk rule. In the Muslim territories of al-Andalus, there were three main "diwan", each of them ruled by a "wazir": "diwan al-rasa'il wa al-kitaba”, for correspondence; "diwan al-kharaj wa al-jibayat", for finances, and "diwan al-jaysh", for the army. The "diwan" also appears during the Ottoman Empire as the "divan-i humayun", the Imperial Council which worked as a cabinet until it was disrupted by the modernizing reforms of the 19th century known as the Tanzimat (Duri et al., 2015).

From all the "diwans" quoted by the Encyclopaedia of Islam, only three of them could be identified as being operated by the Islamic State: "diwan al-sadaqa", "diwan alhisba” (public morals) and "diwan al-mazalim". The overlapping doesn't mean that these institutions have the same prerogatives that they had in the past or that they are organized 
in similar structures. As an example, where our written documents bear signatures in the bottom of the document, the chief of the bureau is either identified as "amir" (commander) or as "mas'ul" (responsible), but the "diwan" in al-Andalus would be ruled by a "wazir" (minister).

The chief of the Bureau of Education, for instance, is both called "mas'ul" and "amir", depending on the document. The signature in some of the documents suggests that the minister of Education in the governorate of Nineveh is a figure known as Dhu al-Qarnayn, "he who has two horns", identified by news reports as an Egyptian extremist (Joumah, 2014).

Insofar as our corpus does not represent the whole of the structure of the Islamic State, being a small (and so far unmeasurable) percentage of it, the statements made above would have to be tested by the gathering of a larger number of documents from a wider territory. It is also noteworthy that, as the denomination of the "diwans" have changed considerably during Islamic history, adapting their functions to the contexts in which they were operated, one should also be careful when comparing former structures with their recent counterparts.

That said, these papers do give us valuable information about at least eight bureaus working in the governorate of Nineveh, in Iraq, those being the already mentioned "diwan [al-zakat wa] al-sadaqa”, "diwan al-hisba" and "diwan [al-qada' wa] al-mazalim" and another five of them: "diwan al-ta 'lim", "diwan al-khidamat" (services, see below on its meaning), "diwan al-masajid" (mosques), "diwan al-sihha" (health) and "diwan al-rikaz" (gold ore).

As already stated, the Bureau of Education replaced the Ministry of Education, being therefore a clear sign of the appropriation of state structures by the Islamic State, even though the continuity of this office is masked by its change in denomination, from a modern to a historical model. A document issued by the Bureau of Services (KH2) also provides us with information on how the Islamic State built itself over the former administration. This letter, issued on the 14th of October of 2014, orders "all the employees in the services offices" to accept the "official hours", during which they must be present at their desks. Al-Tamimi interpreted this statement as an illustration of "the parasitic cooptation of prior structures rather than a complete re-make," since the "services offices are a standard feature of Iraq's provinces" (Al-Tamimi, 2015). These offices, according to him, deal with public services that include electricity and sanitation.

Some of the documents also offer us a glimpse of the coordination between these bureaus. A statement issued by the Bureau of Health setting regulations for the selling of medicine, for instance, refers to the creation of a Bureau of Alms and Charity and justifies its own ruling by 
quoting "the brothers in the Bureau of Hisba" (S1). A separate paper signed by the "diwan al-qada' wa al-mazalim" (Q1) addresses directly the Bureau of Health when establishing the possibility of confiscating the properties of those who fled the lands of the caliphate.

\title{
3. 3. Islamic governance
}

Beyond the analysis of the Islamic State's structure provided by its written documents, we can further infer into this terror organization's views on Islamic governance by looking carefully at the decisions issued by its bureaus. If we take Hallaq's study of the Islamic state, which he sees as a concept that does not fit in a world order based on the modern state (Hallaq, 2013), there is a great deal to say about the Bureau of Education and its decisions. For that we would focus on T1, T2, T3, T4 and T5, but most specifically on T1 and T5.

T1 and T5 both institute, as already discussed, a change from a "ministry" of education to a "bureau". But these two papers also share their content in the sense that they clearly show an organizational view that sees education as a strategic field under its rule. T1, issued on the 24th of October 2014, deals with university exams

\begin{abstract}
for all specialities with the exception of the colleges, departments and subjects that are not legitimate according to Shari'a. Those have been shut down and they are: [...] college of law ${ }^{13}$, political science and fine arts. Archeology, physical education and philosophy department. Department of management of tourism and hotel institutions (T1).
\end{abstract}

The Bureau of Education also forbids, in the same document, "subjects illegitimate according to Shari a", those being democracy, culture, freedoms, rights, fiction and theater in English and French languages and translation departments. "No giving place for special questions on usury interests, principles of nationalism, racism, pseudo-historical events or geographical divisions that also contravene Islamic Shari`a" (T1).

T5 also rules on exams, but for lower levels (middle, preparatory, final). It schedules tests in all subjects and studies except those that "contravene the Hanif law: art, music, nationalist and societal education, as well as philosophy and psychology programs in addition to Christian religious education".

This take on education, with a bureaucratic strong hand dealing with its curriculum and practices, wouldn't fit Islamic governance as it is described by Hallaq. It would rather apply to the conception of a modern state, to which

\footnotetext{
${ }^{13}$ Tamimi translates T1 as banning the "college of human rights", but the original document mentions a "kuliat al-huquq", which we would rather understand as a "college of law".
} 
Crude physical force was not enough, and this the European rulers understood. The population had to be educated in the ways of good conduct, and good conduct meant social order and, in a thoroughly capitalist system, an ability to work and produce. Discipline thus translated into a site in which the subject was corralled into a system of order and instrumental utility. The system that was adopted to accomplish this regulative mechanism was the school (Hallaq, 2013: 100).

Whereas, according to him, Islamic governance was one in which

Emirs and viziers did establish institutions for higher learning (madrasas), but like the judges they appointed and dismissed, they had no influence over what was taught and how. The subjects of education - mostly taught outside of royal madrasas - long remained those that were essential for the law and for satisfying the needs of society, i.e., for leading to the desideratum of the good life (Hallaq, 2013: 110).

The Islamic State view on education also does not find historical grounds on the medieval "madrasas", in which there was "no institutional structure, no curriculum and no regular examination". The interest of the ruling elites "did not extend to any systematic effort to guide educational life or shape its purposes" and "the academic activities they supported [...] were not subjected to systematic governmental regulation and control" (Berkey, 2007: 43-45).

This distinction between Islamic governance and the modern state reinforces the view sustained by Hallaq that Islamic governance does not fit within the structure of the modern state, which is related to a particular European historical development. This means that the very identity of the self is perceived in a different fashion (Hallaq, 2013: 96). What we see by reading the written documents issued by the Islamic State is that their view of a state is determined by a modern Western experience, which would by itself pose a serious challenge to assumptions that the declaration of a caliphate in Raqqa instituted an Islamic governance identical to its historical model. That also convinces us that the Islamic State is, despite its claims on religious and historical grounds, a product of its modern context.

We have so far no reliable information on how the Islamic State judges and enforces Islamic law. But from reading our corpus it is patent that its decisions are being presented as a set of rules "according to the Shari'a" (as it is stated in T1 and S1) with the prescription of reactions when dealing with situations that "contravene Islamic Shari'a" (as in T5). That vision regarding Islamic law is also present in a letter issued by the Bureau of Mosques, in which the law is presented as a blessing from God. And it informs readers

that the Shari`a judiciary has opened its doors and the Shari`a judiciary has decided on rule by the book of God and so it is not allowed for anyone to assume its place in any form like the holding of marriage according to Shari a which is of the right of the Shari'a judiciary, thus holding marriage outside the Shari'a court is forbidden (M1). 
Further analysis would be necessary, in another study, to establish what is the real role of Shari'a in this terror organization, and the extent in which it corresponds to the historical developments of Islamic law over the last centuries, as both Hallaq (2013) and Feldman described it (2008). If sovereignty is thus given back to God, then it would contradict considerably the modern conception of governance, in which the state is the sovereign in itself and in which legislation is not restricted to legislative bodies, despite the ideal of the separation of powers (Hallaq, 2013: 40).

Another aspect worth noting in our documents considering Islamic governance relates to the Bureau of Public Morals, presented in Arabic as the "diwan al-hisba". According to Al-Tamimi, this office deals with the enforcement of public morality.

For example, if someone is caught in possession of alcohol, cigarettes or drugs,
then that person is to be apprehended by the Islamic police and in theory sent
to the diwan al-hisba, which will then decide on the appropriate punishment. In
such cases, a flogging is the standard punishment, though the Islamic police may
sometimes implement it immediately on the spot (Al-Tamimi, 2015).

According to the Encyclopaedia of Islam, "hisba" is a non-Quranic term "used to mean on the one hand the duty of every Muslim to promote good and forbid evil ${ }^{14}$ and, on the other, the function of the person who is effectively entrusted in a town with the application of this rule". This office first appeared during the 9th century and, at the end of the Middle Ages, declined in esteem. "The muhtasib continued to exist throughout the greater part of the Muslim world until the reforms of the modern period; he still existed for example at the beginning of the 20th century in Morocco" (Cahen et al., 2015). An indication of its relevance for the administration of urban centers is the survival of this institution in Iberia after the conquest of Muslim territories (Chalmeta Gendrón, 1973) ${ }^{15}$.

The document issued by the Islamic State indicates that this office has been revived in its territory, where it enforces public morality. This note deals specifically with the closing of shops during prayer times, justifying this measure by quoting the Quran and the Sunna. In the event of contravention, the offender "will be subject to consequences legitimate according to Shari'a resulting in the closing of his shop for a decreed period, with the rest of the necessary proceedings to be undertaken with regards to that person" (H1).

Mawardi dedicates the last chapter of his Ordinances of Government to the market supervisor's office (another denomination for the "hisba", since it was mainly related to that field). He notes that the muhtasib "may penalise for evident violation without reaching the level of legal punishment" (Mawardi, 2010: 260). In this duty, the author states, "his office

\footnotetext{
${ }^{14} \mathrm{On}$ this important Islamic precept and its individual application see COOK, M. Commanding right and forbidding wrong in Islamic thought. Cambridge, UK: Cambridge University Press, 2011 (non vidi).

${ }^{15}$ CHALMETA GENDRON, P. El señor del zoco en españa. Madrid: Inst. Hispano-Arabe de Cultura, 1973 (non vidi).
} 
is created to intimidate, so that overbearing and harshness in the exercise of it may not be considered to exceed the limits or break the rules" (Mawardi, 2010: 262). His further view of the office of "hisba", when dealing specifically with the absence during prayer, nevertheless reaches the conclusion that "as to missing the Friday prayer by an individual person, or not calling to or performing [other] prayers, the public morals official is not to take action against it so long as the offender does not make it his habit and usual behavior" (Mawardi, 2010: 264)

Overall the establishment of a Bureau of Public Morality is another clear sign that the Islamic State is aiming to create Islamic governance that resembles what they see as the paradigm of an ideal Islamic state, despite the fact that, as we saw concerning the Bureau of Education, these views sometimes bear traces of a modern conception of the state. This is also true of the very name of the Islamic State since

The neologisms al-Hukuma al-Islamiyya ('Islamic government') and al-Dawla alIslamiyya ('the Islamic state') were coined in the twentieth century and cannot claim an older pedigree, despite blank statements to the contrary made by Qutbian Islamists in particular (Afsaruddin, 2006: 164).

The reconstruction of these historical structures is also seen on Q1, a paper issued by the "diwan al-qada' wa al-mazalim" threatening doctors who fled Mosul with confiscating their properties in case they fail to return in ten days to the lands of the caliphate. This bureau refers to the traditional office of the "mazalim", "through which the temporal authorities took direct responsibility for dispensing justice". The jurisdiction of the "mazalim" was very wide, "receiving and processing petitions against official and unofficial abuse of power" and also functioning "as a court of appeal against the decisions of qadis" (Nielsen, 2015). This parallel judiciary institution was described by Mawardi as "a special office in which executive might blended with judicial fairness" and being thus necessary to "deter aggression and ensure that justice is done to the victim" (Mawardi, 2010: 88).

The "redress of wrongs" is seen by Mawardi as an instrument towards justice established by the "awesome presence of the person in office," convincing plaintiffs "to accept an equitable settlement and end their dispute" (Mawardi, 2010: 87). As such this institution has a precedent in a tradition that says that Muhammad personally attended to the settlement of a water-drawing dispute. The office of the Mazalim was, according to Mawardi, first established by Umar ibn Abd al-Aziz (d. 720). The Ordinances of Government points to ten classes of action in which the Mazalim could be required, including cases of oppression of the public by government officials. But we could not properly fit the document Q1 in any of his descriptions, when the Islamic State discusses property confiscation. A solution would be reading it in the "fifth class" of actions that "has to do with restoration of usurped property", but Mawardi seems to have had in mind the address of specific cases 
in which the state illegally seized property, or in which it restored property illegally taken by "bullies who simply lay their hands on other people's property" (Mawardi, 2010: 92).

\section{FINAL REMARKS}

In the introduction of this paper, the importance of studying the terror organization Islamic State at its face value as well as of understanding it in one of its distinctive traits (the institution of a state-like structure) was highlighted. But the discussion presented on these pages also insisted on the further analysis of this image, as would a spectator that first watches the shadows in a theater and then finally sees the puppets that project them.

The Islamic State has established its government as a determinant of its success, and as such it devoted itself to the goal of ruling a complex structure in the territories under its rule. Thus it projects itself. We have here gathered a varied corpus that gives us valuable information of that intent, through a set of documents referring to each other and to a common goal. Scholars can disagree on whether the Islamic State is a state or not, but it seems that a common ground would be agreeing that the documents here analyzed were at least produced to resemble a state.

We have argued here that the project of imposing a classical conception of Islamic governance is contradictory with the inescapable reality of the modern state (an idea extensively discussed by Hallaq). That is specially evident in the educational policies of the Islamic State, that go against the historical view of the caliphate as an entity that cannot interfere on this field. History, on the other hand, presents us with the fact that the idea of what is a caliphate is not at all changeless. The very conception of the times of the first caliphs as a period when orthodoxy reigned, central to the terror organization Islamic State, is a historical development, since

The rationalization of the Sunni doctrine of the imamate was a gradual process which extended over the first four and a half centuries and took into account developments not present in the early days of the caliphate. [Events] all left their mark on the theory of the caliphate as it was developed by the jurists (Lambton, 1981: chapter 2).

Thus classical texts on Islamic governance are always read in the context of their writing, on how they relate to the historical reality; for instance, the fall of a caliphate or the imposition of the rule of new dynasties. We have here focused on Mawardi because of the impact of his work on the idea of the caliphate, but that is also true of thinkers such as Baghdadi, Ghazali and Ibn Taymiyya, all of them studied in their contexts of institutional crisis by a variety of authors that include Lambton (1981), Hillenbrand (1988) and Binder (1955). 
In this sense, we read the documents issued by the Islamic State as a product of their environment, hardly external to history itself. Their views on politics cannot ignore the modern period in which they operate, where we find a state that is diverse from its medieval equivalent, interfering in social spheres previously considered outside its control, such as family and education (Fierro, 1994). In this sense, Hamoudi argued that such projects can be seen as "the vehicle of 'resistance' to a Western dominated global social, economical and political order. It is the product of entirely modern anti-colonialist and regional liberation fervor gripping the region that has no classical antecedent" (2010: 86). 
artigo

\section{Bibliography}

AFSARUDDIN, Asma. The Islamic State: Genealogy, Facts, and Myths. Journal of Church and State, v. 48 n. 1, pp. 153-173, 2006.

AL-TAMIMI, Aymenn J. Archive of Islamic State Administrative Documents. 2015. Available at: www.aymennjawad.org/2015/01/archive-of-islamic-state-administrativedocuments. Access: 27 May 2015.

BERKEY, Jonathan. Madrasa, medieval and modern: politics, education, and the problem of Muslim identity. HEFNER, Robert W. \& ZAMAN, Muhammad Q. (eds.). Schooling Islam: The Culture and Politics of Modern Muslim Education, Princeton: Princeton University Press, 2007.

BINDER, Leonard. Al-Ghazali's Theory of Islamic Government. The Muslim World, v. $45 \mathrm{n}$. 3, pp. 229-241, 1955.

BUNZEL, Cole. From Paper State to Caliphate: The Ideology of the Islamic State. Doha: Brookings Doha Center, 2015. Available at: <http://www.brookings.edu/ /media/ research/files/papers/2015/03/ideology-of-islamic-state-bunzel/the-ideology-of-theislamic-state.pdf> Access: 21 Jun 2015.

CAHEN, Claude; TALBI, Mohamed; MANTRAN, Robert; LAMBTON, Ann K. S. \& BAZMEE ANSARI, A. S. Hisba. BEARMAN, P.; BIANQUIS, Th.; BOSWORTH, C. E.; DONZEL, E. V. \& HEINRICHS, W. P. (eds.) Encyclopaedia of Islam, 2nd ed. Available at: http://referenceworks. brillonline.com.lama.univ-amu.fr/entries/encyclopaedia-of-islam-2/hisba-COM 0293. Access: 16 May 2015.

CALDER, Norman. The limits of Islamic orthodoxy. DAFTARY, Farhad (ed.), Intellectual traditions in Islam, London: I. B. Tauris, 2000. pp. 66-86.

DURI, A., GOTTSCHALK, H., COLIN, G., LAMBTON, A. \& BAZMEE ANSARI, A. S. Diwan. BEARMAN, P.; BIANQUIS, Th.; BOSWORTH, C. E.; DONZEL, E. V. \& HEINRICHS, W. P. (eds.) Encyclopaedia of Islam, 2nd ed. Available at: http://referenceworks.brillonline.com.lama. univ-amu.fr/entries/encyclopaedia-of-islam-2/diwan-COM 0170. Access: 16 May 2015.

FELDMAN, Noah. The fall and rise of the Islamic state [Kindle version]. 2008. Available from: Amazon.com.

FIERRO, Maribel. La legitimidad del poder en el Islam. Awraq, v. 15, 1994. pp. 147-184.

FERJANI, Mohamed-Cherif. Política y religión en el campo islámico. Trans. José M. G. M. Barcelona: Bellaterra, 2009. 
artigo

GÓMEZ GARCÍA, Luz. Diccionario de islam e islamismo. Madrid: Espasa Calpe, 2009.

HALLAQ, Wael. The impossible state [Kindle version], 2013. Available from: Amazon.com.

HAMOUDI, Haider A. Orientalism and The Fall and Rise of the Islamic State. Middle East Law and Governance, v. 2 n. 1, 2010. pp.81-103.

HILLENBRAND, Carole. Islamic Orthodoxy or Realpolitik? Al-Ghazālī's Views on Government. Iran, v. 26, 1988. p.81.

JOUMAH, Khales. The Minister of Education, The Man With Two Horns. Niqash. 2014. Available at: http://www.niqash.org/en/articles/society/3580/. Access: 28 May 2015.

KERSTEN, Carool. The Caliphate In The Modern Muslim World: Political Ideal Or Quranic Metaphor?. 2015. Lecture.

KNYSH, Alexander. Orthodoxy and heresy in Medieval Islam: an essay in reassessment. The Muslim World, v. 83 n. 1, 1993. pp. 48-67.

KURAN, Timur. The long divergence: How Islamic Law Held Back the Middle East. Princeton: Princeton University Press, 2011.

LAMBTON, Ann K. S.. State and government in medieval Islam. Oxford: Oxford University Press, 1981.

LE GOFF, Jacques. História e memória. Trans. Bernardo L. Campinas: Editora da Unicamp, 1990.

LEWIS, Bernard. El lenguage político del Islam. Trans. Mercedes Lucini Baquerizo Madrid: Taurus, 2004.

LISTER, Charles. Profiling the Islamic State. Doha: Brookings Doha Center, 2014. Available at: http://www.brookings.edu/ /media/Research/Files/Reports/2014/11/profilingislamic-state-lister/en web lister.pdf?la=en. Access: 27 May 2015.

MANZANO MORENO, Eduardo. Introduction. SIJPESTEIJN, Petra \& SUNDELIN, Lennart (ed.), From al-Andalus to Khurasan: Documents from the Medieval Muslim World. Boston: Brill Academic Publishers, 2007. p.xvii-xxviii.

MARTÍN, Javier. Estado Islámico. Geopolítica del caos. Madrid: Catarata, 2015.

MAWARDI. The Ordinances of Government. Trans. Wafaa H. Wahba Reading: Garnet, 2010. 
NAJI, Abu B. The Management of Savagery. John M. Olin Institute for Strategic Studies, Harvard University, 2006. Available at: https://azelin.files.wordpress.com/2010/08/ abu-bakr-naji-the-management-of-savagery-the-most-critical-stage-through-which-theumma-will-pass.pdf. Access 15 Jun. 2015.

NAPOLEONI, Loretta. The Islamist Phoenix [Kindle version]. 2014. Available from: Amazon. com.

NIELSEN, Jorgen S. (2015). Mazalim. BEARMAN, P.; BIANQUIS, Th.; BOSWORTH, C. E.; DONZEL, E. V. \& HEINRICHS, W. P. (eds.) Encyclopaedia of Islam, 2nd ed. Available at: http://referenceworks.brillonline.com.lama.univ-amu.fr/entries/encyclopaedia-ofislam-2/mazalim-COM 0721. Access: 16 May 2015.

RAZEK, Ali A. Islam and the Foundations of Political Power [Kindle version]. 2012. Available from: Amazon.com

REUTER, Cristoph. Secret Files Reveal the Structure of Islamic State. Der Spiegel, 2015. Available at: http://www.spiegel.de/international/world/islamic-state-files-showstructure-of-islamist-terror-group-a-1029274.html. Access: 27 May 2015.

SIJPESTEIJN, Petra. Shaping a Muslim state. Oxford: Oxford University Press, 2013.

The Return of Khilafah. Dabiq, 2014. Available at: http://media.clarionproject.org/ files/09-2014/isis-isil-islamic-state-magazine-Issue-1-the-return-of-khilafah.pdf. Access: 28 May 2015.

WEBER, Max. Politics as a Vocation. GERTH, H. \& WRIGHT MILLS, C. (eds.). From Max Weber: Essays in Sociology. Oxford: Oxford University Press, 1946.

WEISS, Michael. \& HASSAN, Hassan. ISIS: Inside the Army of Terror. New York: Regan Arts, 2015.

WOOD, Graeme. What ISIS Really Wants. The Atlantic. 2015. Available at: http://www. theatlantic.com/features/archive/2015/02/what-isis-really-wants/384980. Access: 27 May 2015.

Texto recebido em: 13 de Dezembro de 2016 Aprovado em: 24 de Março de 2017 